\title{
A microarray-based system for the simultaneous analysis of single nucleotide polymorphisms in human genes involved in the metabolism of anti-malarial drugs
}

\author{
Eva Maria Hodel ${ }^{\dagger 1}$, Serej D Ley ${ }^{\dagger 1,4}$, Weihong Qi1,5, Frédéric Ariey², \\ Blaise Genton ${ }^{1,3}$ and Hans-Peter Beck*1
}

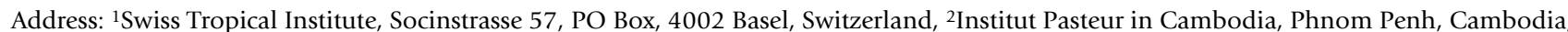
${ }^{3}$ Department of Ambulatory Care and Community Medicine, University of Lausanne, Lausanne, Switzerland, ${ }^{4}$ Papua New Guinea Institute of Medical Research, Goroka, Papua New Guinea and ${ }^{5}$ Functional Genomics Center Zurich, Zurich, Switzerland

Email: Eva Maria Hodel - Eva-Maria.Hodel@unibas.ch; Serej D Ley - Serej.Ley@unibas.ch; Weihong Qi - Weihong.Qi@fgcz.ethz.ch; Frédéric Ariey - fariey@pasteur-kh.org; Blaise Genton - Blaise.Genton@unibas.ch; Hans-Peter Beck* - Hans-Peter.Beck@unibas.ch

* Corresponding author †Equal contributors
\end{abstract}

Published: 9 December 2009

Malaria Journal 2009, 8:285 doi:10.1 I86/1475-2875-8-285

This article is available from: http://www.malariajournal.com/content/8/I/285

(C) 2009 Hodel et al; licensee BioMed Central Ltd.

This is an Open Access article distributed under the terms of the Creative Commons Attribution License (http://creativecommons.org/licenses/by/2.0), which permits unrestricted use, distribution, and reproduction in any medium, provided the original work is properly cited.
Received: 2I August 2009

Accepted: 9 December 2009

\begin{abstract}
Background: In order to provide a cost-effective tool to analyse pharmacogenetic markers in malaria treatment, DNA microarray technology was compared with sequencing of polymerase chain reaction (PCR) fragments to detect single nucleotide polymorphisms (SNPs) in a larger number of samples.

Methods: The microarray was developed to affordably generate SNP data of genes encoding the human cytochrome P450 enzyme family (CYP) and N-acetyltransferase-2 (NAT2) involved in antimalarial drug metabolisms and with known polymorphisms, i.e. CYP2A6, CYP2B6, CYP2C8, CYP2C9, CYP2C19, CYP2D6, CYP3A4, CYP3A5, and NAT2.

Results: For some SNPs, i.e. CYP2A6*2, CYP2B6*5, CYP2C8*3, CYP2C9*3/*5, CYP2C19*3, CYP2D $6 * 4$ and $N A T 2 * 6 / * 7 / * 14$, agreement between both techniques ranged from substantial to almost perfect (kappa index between $0.6 \mathrm{I}$ and $\mathrm{I} .00$ ), whilst for other SNPs a large variability from slight to substantial agreement (kappa index between 0.39 and I.00) was found, e.g. CYP2D6*17 $(2850 \mathrm{C}>\mathrm{T}), \mathrm{CYP} 3 A 4 * I B$ and CYP3A5*3.
\end{abstract}

Conclusion: The major limit of the microarray technology for this purpose was lack of robustness and with a large number of missing data or with incorrect specificity.

\section{Background}

Drug action depends on how drugs are metabolized and differences in activity of metabolizing enzymes can significantly contribute to the efficacy of drugs $[1,2]$. This might also be true for drugs given to treat malaria. The objective was to analyse single nucleotide polymorphisms (SNPs) in genes encoding enzymes implicated in metabolizing anti-malarial drugs in order to determine the contribution of these enzymes to the pharmacokinetics of the specific drugs. There are many methods available for the detection of SNPs (for review see $[3,4]$ ). These methods are either based on allele-specific hybridization or on primer extension reaction. Many of these techniques are time consuming, expensive and/or not suitable for use in resource-poor 
countries. Previously, a cost-effective DNA microarraybased [5] technique to detect SNPs associated with drug resistance in malaria parasites in a larger sample size has been developed and successfully used. To test whether this system also could be used for SNP determination in metabolizing enzyme genes, microarray determined SNPs were compared with sequencing. For this, a microarray was developed to affordably generate SNP data on genes encoding the human cytochrome P450 enzyme family (CYP) and N-acetyltransferase-2 (NAT2) involved in antimalarial drug metabolisms. The performance of this microarray had to be determined subsequently. The microarray was designed to analyse enzyme genes with known polymorphisms such as CYP2A6 and CYP2B 6 for the artemisinins, CYP2C8 for amodiaquine, chloroquine and dapsone, CYP2C9 and NAT2 for dapsone and sulphamethoxazole, CYP2C19 for dapsone and proguanil, CYP2D6 for chloroquine and halofantrine, CYP3A4 for the artemisinins, chloroquine, dapsone, halofantrine, lumefantrine, mefloquine, primaquine and quinine, and CYP3A5 for artemether, $\beta$-arteether, chloroquine, mefloquine, quinine and sulphadoxine [6-29]. For certain antimalarial drugs (piperaquine, pyrimethamine and pyronaridine) the metabolic pathway is yet not well known, while others (atovaquone and doxycycline) are barely metabolized at all [30-35].

\section{Methods}

\section{Study population}

During an in vivo drug efficacy study in patients with uncomplicated malaria of all age, venous blood samples (anticoagulated using EDTA) were obtained after informed consent from 125 patients in Northern and Western Cambodia (64 in 2007 at Phnom Dék Health Centre, Rovieng district, Preah Vihear province, and 61 in 2008 at Pramoy Health Centre, Veal Veng district, Pursat province) and 149 patients in Central Tanzania (in 2008 at Kibaoni Health Centre, Kilombero district, Morogoro region).

\section{Sequencing}

Genomic DNA was extracted from $200 \mu$ whole blood using the QIAamp 96 DNA Blood Kit (QIAGEN GmbH, Germany) according to the manufacturer's instructions.

Target sequences in cyp and nat 2 genes of these samples were amplified using PCR. The PCR primers used are listed in Table 1. The amplified regions contained SNPs which are known to alter the function of enzymes involved in the metabolism of anti-malarial drugs (for target loci and effect of the SNP see Table 1). The PCR master mix contained $1 \times$ reaction buffer B (Solis BioDyne, Estonia), $1 \times$ solution $\mathrm{S}$ (Solis BioDyne, Estonia), $10 \mu \mathrm{M}$ of each primer in $1 \times$ Tris-EDTA (see Table 1, Operon Biotechnologies $\mathrm{GmbH}$, Germany), $\mathrm{MgCl}_{2}$ (according to
Table 1, Solis BioDyne, Estonia), $2 \mathrm{mM}$ of each dNTP in Tris-HCl $10 \mathrm{mM}, \mathrm{pH} 7.4$ (GE Healthcare, Switzerland) and 2 U FIREPol DNA polymerase (Solis BioDyne, Estonia). $1 \mu \mathrm{l}$ of extracted DNA was mixed with $24 \mu \mathrm{l}$ of PCR master mix. The PCR protocol was $3 \mathrm{~min}$ at $96^{\circ} \mathrm{C}$ followed by 40 cycles $\left(30 \mathrm{sec}\right.$ at $96^{\circ} \mathrm{C}, 1 \mathrm{~min} 30 \mathrm{sec}$ at 56 $64^{\circ} \mathrm{C}$ according to Table 1 and $1 \mathrm{~min} 30 \mathrm{sec}$ at $72^{\circ} \mathrm{C}$ ) with a final elongation for $10 \mathrm{~min}$ at $72^{\circ} \mathrm{C}$. PCR products were purified and sequenced by Macrogen (Macrogen Ltd., Korea). ABI Prism AutoAssembler version 1.4.0 (Applied Biosystems) was used for assembly and analysis of sequences. The genotype of each patient was then assessed visually. Aliquots of the same PCR products were used for primer extension and microarray analysis.

\section{Patient selection for DNA microarray validation}

Of 274 patients from Cambodia and Tanzania, 96 were selected (i.e. to fit 96-well plate) for validation of the microarray. Samples were selected by the number of successfully sequenced SNPs and then their ID number. For all 96 selected samples at least 16 out of 18 SNPs have been successfully sequenced.

\section{Extension control and elimination of non-incorporated nucleotides}

As extension control for the microarray, amplified nested PCR product from the Plasmodium falciparum chloroquine resistance transporter gene ( $p f c r t)$ from strains 3D7 (wildtype at loci $p f c r t 76$ and $p f c r t 97$ ) and $\mathrm{K} 1$ (mutation at locus $p f c r t 76$ and wild-type at pfcrt97) were mixed at a ratio of 55\%:45\%. Primers and PCR conditions have been described elsewhere [5].

To eliminate non-incorporated nucleotides prior to primer extension, all nested PCR products of one blood sample were pooled and $10 \mu \mathrm{l}$ of the pooled PCR products and $0.5 \mu \mathrm{l}$ of the extension control mix were digested with $8 \mathrm{U}$ shrimp alkaline phosphatase (SAP) and $4 \mu \mathrm{l} 10 \times \mathrm{SAP}$ buffer (both Amersham Biosciences, Freiburg, Germany) in a reaction volume of $48 \mu \mathrm{l}$ for $1 \mathrm{~h}$ at $37^{\circ} \mathrm{C}$. SAP was inactivated by incubating samples for $15 \mathrm{~min}$ at $90^{\circ} \mathrm{C}$.

\section{Primer extension and denaturation}

Since the microarray scanner used only supported dualfluorescence measures simultaneously and because of the large similarity of the cyp genes, a strategy of three parallel reactions with different primer and dye combinations had to be applied. Different extension primer mixes (I, II and III) were prepared according to Table 2, each with a total volume of $320 \mu \mathrm{l}$ containing the corresponding primers (62.5 nM final concentration of each primer, Operon Biotechnologies GmbH, Germany) diluted in $1 \times$ Tris-EDTA (TE). Afterwards, three extension mixes (I, II and III) were prepared (final volume of $8 \mu \mathrm{l}$ ) containing $2 \mathrm{U}$ of HOT TERMIPol $^{\circledast}$ DNA Polymerase (Solis BioDyne, Estonia), 1.8 
Table I: Primers used to amplify target sequences in cytochromes $\mathbf{P 4 5 0}$ isoenzymes and $\mathbf{N}$-acetyltransferase 2 genes, $\mathrm{MgCl}_{2}[\mu \mathrm{l}]$ for the master mix and annealing temperature $\left[{ }^{\circ} \mathrm{C}\right]$ used to amplify target sequence in cytochromes $\mathrm{P} 450$ isoenzyme genes and $\mathrm{N}$ acetyltransferase 2 genes.

\begin{tabular}{|c|c|c|c|c|}
\hline SNP & primer & Sequence & $\mathrm{MgCl}_{2}[\mu \mathrm{l}]$ & $\mathbf{T}\left[{ }^{\circ} \mathrm{C}\right]$ \\
\hline CYP2A6*2 (479T>A, LI60H) & $\begin{array}{l}\text { forward } \\
\text { reverse }\end{array}$ & $\begin{array}{l}\text { 5'-TCTCTCTCTCTACCTCGACAT-3' } \\
\text { 5'-GTTCCTCGTCCTGGGTGTT-3' }\end{array}$ & 3 & 64 \\
\hline CYP2B6*5 (I459C>T, R487C) & $\begin{array}{l}\text { forward } \\
\text { reverse }\end{array}$ & $\begin{array}{l}\text { 5'-CCAGAAGACATCGATCTGAC-3' } \\
\text { 5'-TCTCTCAGAGGCAGGAAGTT-3' }\end{array}$ & 2 & 64 \\
\hline CYP2B6*6 (5I6G>T, QI72H) & $\begin{array}{l}\text { forward } \\
\text { reverse }\end{array}$ & $\begin{array}{l}\text { 5'-TGAGTGATGGCAGACAATCACA-3' } \\
\text { 5'-CAAGTTGAGCATCTTCAGGAACT-3' }\end{array}$ & 2 & 64 \\
\hline CYP2C8*3 (4I6G>A, RI39K) & $\begin{array}{l}\text { forward } \\
\text { reverse }\end{array}$ & $\begin{array}{l}\text { 5'-CTAAAGGACTTGGTAGGTGCA-3' } \\
\text { 5'-CAGGATGCGCAATGAAGACC-3' }\end{array}$ & 2 & 64 \\
\hline CYP2C9*3/*5 (I075A>C, 1359L//080C>G, D360E) & $\begin{array}{l}\text { forward } \\
\text { reverse }\end{array}$ & $\begin{array}{l}\text { 5'-CTGGTTTATGGCAGTTACACATT-3' } \\
\text { 5'-GAGAAAGTCCAGTTAAACTGCC-3' }\end{array}$ & 2 & 64 \\
\hline CYP2C19*3 (636G>A, W212X) & $\begin{array}{l}\text { forward } \\
\text { reverse }\end{array}$ & $\begin{array}{l}\text { 5'-GGGAATTCATAGGTAAGATATTA-3' } \\
\text { 5'-GGAGTGATATAAGCACGCTTTG-3' }\end{array}$ & 2 & 64 \\
\hline CYP2D6*4 (I846G>A, splicing defect) & $\begin{array}{l}\text { forward } \\
\text { reverse }\end{array}$ & $\begin{array}{l}\text { 5'-CCGCCTTCGCCAACCACT-3' } \\
\text { 5'-CCCTGCAGAGACTCCTCGGT-3' }\end{array}$ & 2 & 64 \\
\hline CYP2D6*10 (100C>T, P34S $)$ & $\begin{array}{l}\text { forward } \\
\text { reverse }\end{array}$ & $\begin{array}{l}\text { 5'-CCCATTTGGTAGTGAGGCAGGT-3' } \\
\text { 5'-CСССTTCTCAGCCTGGCTTCTTG-3' }\end{array}$ & 2 & 64 \\
\hline CYP2D6*10 (4180G>C, S486T) & $\begin{array}{l}\text { forward } \\
\text { reverse }\end{array}$ & $\begin{array}{l}\text { 5'-AGCCACCATGGTGTCTTTGCT-3' } \\
\text { 5'-TTGCCCTGAGGAGGATGATC-3' }\end{array}$ & 2 & 64 \\
\hline CYP2D6*I7 (I023C>T, TI07I) & $\begin{array}{l}\text { forward } \\
\text { reverse }\end{array}$ & $\begin{array}{l}\text { 5'-CGCGAGGCGCTGGTGACCAA-3' } \\
\text { 5'-CCAGCTCGGACTACGGTCATCAC-3' }\end{array}$ & 2 & 64 \\
\hline CYP2D6*I7 (2850C>T, R296C) & $\begin{array}{l}\text { forward } \\
\text { reverse }\end{array}$ & $\begin{array}{l}\text { 5'-GACTCTGTACCTCCTATCCACGTCA-3' } \\
\text { 5'-TCCCTCGGCCCCTGCACTGTTT-3' }\end{array}$ & 2 & 64 \\
\hline CYP3A4*IB $(-392 A>G)$ & $\begin{array}{l}\text { forward } \\
\text { reverse }\end{array}$ & $\begin{array}{l}\text { 5'-CTCACCTCTGTTCAGGGAAAC-3' } \\
\text { 5'-ATGGCCAAGTCTGGGATGAG-3' }\end{array}$ & 2 & 64 \\
\hline CYP3A5*3 (6986A>G, splicing defect) & $\begin{array}{l}\text { forward } \\
\text { reverse }\end{array}$ & $\begin{array}{l}\text { 5'-TGGAGAGTGGCATAGGAGATAC-3' } \\
\text { 5'-CCATACCCCTAGTTGTACGACACA-3' }\end{array}$ & 2.5 & 64 \\
\hline $\begin{array}{l}\text { NAT2*5/*6/*7/*I4 } \\
(34|\mathrm{I}>\mathrm{C}, \mathrm{II}| \mathrm{IT} / 590 \mathrm{G}>\mathrm{A}, \mathrm{R} / 97 \mathrm{Q} / 857 \mathrm{G}>\mathrm{A}, \mathrm{G} 286 \mathrm{E} / \\
\text { I } 9 \mid \mathrm{G}>\mathrm{A}, \mathrm{R} 64 \mathrm{Q})\end{array}$ & $\begin{array}{l}\text { forward } \\
\text { reverse }\end{array}$ & $\begin{array}{l}\text { 5'-GGGATCATGGACATTGAAGCATATT-3' } \\
\text { 5'-ACGTGAGGGTAGAGAGGATATCTG-3' }\end{array}$ & 2 & 64 \\
\hline
\end{tabular}

Primers highlighted in bold were used for sequencing. SNP positions are indicated in brackets; they were obtained from the Home Page of the Human Cytochrome P450 (CYP) Allele Nomenclature Committee [4I], and the Consensus Human Arylamine N-Acetyltransferase Gene Nomenclature [44].

$\mu \mathrm{l}$ of $10 \times$ Reaction Buffer C (Solis BioDyne, Estonia), 2.5 $\mathrm{mM} \mathrm{MgCl}$, and $0.625 \mu \mathrm{M}$ of the corresponding Cy3- and Cy5-labeled ddNTPs (Perkin Elmer, Schwerzenbach, Switzerland); ddNTP mixes are listed in Table 3. Then, $12 \mu \mathrm{l}$ SAP digested PCR product of each patient were mixed with $8 \mu \mathrm{l}$ of the extension mix I, II or III, respectively. The following primer extension protocol was used: $1 \mathrm{~min}$ at $94^{\circ} \mathrm{C}$ followed by 40 cycles of $10 \mathrm{sec}$ at $94^{\circ} \mathrm{C}$ followed by
$40 \mathrm{sec}$ at $50^{\circ} \mathrm{C}$. The three mixes of each patient were then pooled again in a 96 well plate and mixed with $10 \mu \mathrm{l}$ of the hybridization buffer. The hybridization buffer contained $37.5 \mu \mathrm{M}$ EDTA pH 8.0, $7 \mathrm{pM}$ of two differently labelled positive hybridization controls 5'-GCCTCCACGCACGTTGTGATATGTA- [Cy3]-3' and 5'- CTGTGACAGAG CCAACACGCAGTCT- [Cy5]-5' (Operon Biotechnologies GmbH, Germany), and 3\% sodium dodecyl sulphate 
Table 2: Extension primers of three parallel mixes.

\begin{tabular}{|c|c|c|}
\hline SNP & Primer & Mix \\
\hline CYP2C8*3.I & 5'-GGAATTTTGGGATGGGGAAGA-3' & 1 \\
\hline CYP $2 A 6 * 2$ & 5'-GCTTCCTCATCGACGCCC-3' & i \\
\hline CYP2D $6 * 4$ & 5'-CCGCATCTCCCACCCCCA-3' & i \\
\hline CYP2D $6 * 10(100 C>T)$ & 5'-ACGCTGGGCTGCACGCTAC-3' & I \\
\hline CYP2D6*I 7 (2859C>T) & 5'-AGCTTCAATGATGAGAACCTG-3' & 1 \\
\hline CYP2D6*17 $(1023 C>T)$ & 5'-CCCGAAACCCAGGATCTGG-3' & i \\
\hline CYP 3 A $5 * 3$ & 5'-TGGTCCAAACAGGGAAGAGATA-3' & 1 \\
\hline CYP3A4*IB & 5'-CATAAAATCTATTAAATCGCCTCTCTC-3' & 1 \\
\hline E. CYP2C $9 * 3$ & 5'-TGCACGAGGTCCAGAGATAC-3' & II \\
\hline E. CYP2C9*5 & 5'-CAGGCTGGTGGGGAGAAG-3' & II \\
\hline E. CYP2B6*6 (5I6G>T) & 5'-AGATGATGTTGGCGGTAATGGA-3' & II \\
\hline E. CYP2D $6 * 10(4180 \mathrm{G}>C)$ & 5'-GTGTCTTTGCTTTCCTGGTGA-3' & II \\
\hline pfcrt76 & 5'-TTTGTTTAAAGTTCTTTTAGCAAAAATT-3' & II \\
\hline pfcrt97 & 5'-GTTTTGTAACATCCGAAACTCA-3' & II \\
\hline NAT2*7 & 5'-GTGCCCAAACCTGGTGATG-3' & III \\
\hline NAT2* 14 & 5'-TTGATCACATTGTAAGAAGAAACC-3' & III \\
\hline CYP2C19*3 & 5'-AGGATTGTAAGCACCCCCTG-3' & III \\
\hline CYP2B $6 * 5$ & 5'-TACCCCCAACATACCAGATC-3' & III \\
\hline NAT2*5 & 5'-CTTCTCCTGCAGGTGACCA-3' & III \\
\hline NAT2*6 & 5'-TATACTTATTTACGCTTGAACCTC-3' & III \\
\hline
\end{tabular}

(SDS). The plate was incubated for $1 \mathrm{~min}$ at $94^{\circ} \mathrm{C}$ and immediately chilled on ice for $2 \mathrm{~min}$.

\section{Microarray production and microarray hybridization}

Aldehyde-activated ArrayIt ${ }^{\circledR}$ SuperAldehyde 2 glass slides with SuperMask ${ }^{\mathrm{TM}} 16$ (EBN European Biotech Network, Dolembreux, Belgium) were used. Oligonucleotides (Operon Biotechnologies GmbH, Germany) corresponding to the antisense DNA of the extension primers, extension controls (Table 2) and positive hybridization controls were spotted onto the microarrays in triplicate. The spotting was done by the DNA Array Facility of the Center for Integrative Genomics, University of Lausanne,

Table 3: Labelled ddNTPs used for the three parallel extension mixes.

\begin{tabular}{ll}
\hline ddNTP and label & Mix \\
\hline ddATP Cy3 & I \\
ddCTP Cy3 & \\
ddGTP Cy5 & \\
ddUTP Cy5 & $\mathbb{I}$ \\
\hline ddATP Cy5 & \\
ddCTP Cy3 & \\
ddGTP Cy5 & \\
ddUTP Cy3 & \\
\hline ddATP Cy3 & \\
ddCTP Cy5 & \\
ddGTP Cy5 \\
ddUTP Cy5
\end{tabular}

Switzerland, using solutions of $50 \mu \mathrm{M}$ oligonucleotide in $180 \mathrm{mM}$ phosphate buffer ( $\mathrm{pH}$ 8.0). All oligonucleotides had a C7-aminolinker attached to the 3' end. Anchor oligonucleotides prelabeled with Cy3 and Cy5 and four oligonucleotides with a random sequence were added as positive and negative controls, respectively. Of the pooled and denatured primer extension reaction mixture $35 \mu \mathrm{l}$ were transferred to one well of the microarray, and $6 \mu \mathrm{l} 20$ $\times$ Standard Saline Citrate (SSC) were added. In each well, representing a single microarray, DNA from one patient was hybridized. Hybridization was carried out in a humid chamber at $50^{\circ} \mathrm{C}$ for $90 \mathrm{~min}$. After hybridization, the slide was washed at room temperature in $2 \times$ SSC with $0.2 \%$ SDS for 10 min, followed by a wash with $2 \times$ SSC for 10 min, and a final wash with $2 \times$ SSC plus $2 \%$ ethanol for 2 min. These three steps represent the first wash step. Slides were dried with compressed air.

\section{Data acquisition}

Microarrays were scanned at $635 \mathrm{~nm}$ and $532 \mathrm{~nm}$ using an Axon 4100A fluorescence scanner (Bucher Biotec AG, Basel, Switzerland). After the first scan slides were washed and scanned again and after each wash, Cy3 and Cy5 images were acquired and analysed using the Axon GenePix Pro software (version 6.0). An in house developed perl script based on Kestler's statistics module [36] was used to call SNPs based on probe signal intensities. The script calculates receiver operating characteristic (ROC) curves using signal intensity values from the set of positive and negative controls for each hybridization. Hybridization specific thresholds that maximize both sensitivity and specificity were then used to make SNP calls. 
Table 4: Comparison of SNP data acquired either by sequencing or DNA microarray technology.

\begin{tabular}{|c|c|c|c|c|c|c|c|c|}
\hline \multirow[b]{2}{*}{ SNP } & \multirow[b]{2}{*}{ Country } & \multicolumn{3}{|c|}{ I st wash } & \multicolumn{3}{|c|}{$2^{\text {nd }}$ wash } & \multirow[b]{2}{*}{ Agreement } \\
\hline & & $\kappa$ & $n$ & $\%$ & $\kappa$ & $n$ & $\%$ & \\
\hline \multirow[t]{2}{*}{ CYP2A6*2 } & Cambodia & 0.87 & 24 & 88.9 & 0.92 & 19 & 70.4 & Substantial to almost \\
\hline & Tanzania & 0.83 & 58 & 82.9 & 0.61 & 53 & 75.7 & perfect \\
\hline \multirow[t]{2}{*}{ CYP2B6*5 } & Cambodia & 0.94 & 27 & 100.0 & 0.94 & 27 & 100.0 & Almost perfect \\
\hline & Tanzania & 0.92 & 67 & 95.7 & 0.86 & 67 & 95.7 & \\
\hline \multirow[t]{2}{*}{ CYP2B6*6 } & Cambodia & 0.42 & 26 & 96.3 & 0.42 & 27 & 100.0 & Fair to moderate \\
\hline & Tanzania & 0.35 & 63 & 90.0 & 0.40 & 59 & 84.3 & \\
\hline \multirow[t]{2}{*}{ CYP2C $8 * 3$} & Cambodia & 0.97 & 20 & 74.1 & 1.00 & 20 & 74.1 & Substantial to almost \\
\hline & Tanzania & 0.90 & 39 & 55.7 & 0.79 & 38 & 54.3 & perfect \\
\hline \multirow[t]{2}{*}{ CYP2C9*3 } & Cambodia & 0.92 & 26 & 96.3 & 0.94 & 26 & 96.3 & Almost perfect \\
\hline & Tanzania & 0.90 & 67 & 95.7 & 0.82 & 64 & 91.4 & \\
\hline \multirow[t]{2}{*}{ CYP2C9*5 } & Cambodia & 0.98 & 27 & 100.0 & 1.00 & 27 & 100.0 & Almost perfect \\
\hline & Tanzania & 0.93 & 67 & 95.7 & 0.86 & 70 & 100.0 & \\
\hline \multirow[t]{2}{*}{$\mathrm{CYP} 2 \mathrm{Cl} 19 * 3$} & Cambodia & 1.00 & 27 & 100.0 & 1.00 & 26 & 96.3 & Almost perfect \\
\hline & Tanzania & 0.90 & 97 & 95.7 & 0.83 & 66 & 94.3 & \\
\hline \multirow[t]{2}{*}{ CYP2D $6 * 4$} & Cambodia & 0.98 & 26 & 96.3 & 1.00 & 26 & 96.3 & Almost perfect \\
\hline & Tanzania & 0.91 & 63 & 90.0 & 0.88 & 65 & 92.9 & \\
\hline \multirow{2}{*}{ CYP2D6*10 $(100 \mathrm{C}>\mathrm{T})$} & Cambodia & 0.59 & 24 & 88.9 & 0.64 & 20 & 74.1 & Moderate to substantial \\
\hline & Tanzania & 0.72 & 31 & 44.3 & 0.76 & 27 & 38.6 & \\
\hline \multirow[t]{2}{*}{ CYP2D6*I0 $(4 \mid 80 \mathrm{G}>\mathrm{C})$} & Cambodia & 0,40 & 21 & 77.8 & 0.50 & 17 & 63.0 & Fair to moderate \\
\hline & Tanzania & 0.45 & 45 & 64.3 & 0.51 & 38 & 54.3 & \\
\hline \multirow[t]{2}{*}{ CYP2D6*I7 $(1023 C>T)$} & Cambodia & 0.86 & 19 & 70.4 & 1.00 & 6 & 22.2 & Moderate to almost \\
\hline & Tanzania & 0.59 & 37 & 52.9 & 0.49 & 37 & 52.9 & perfect \\
\hline \multirow[t]{2}{*}{ CYP2D6*I7 $(2850 C>T)$} & Cambodia & 0.29 & 7 & 25.9 & 0.20 & 6 & 22.2 & Slight to substantial \\
\hline & Tanzania & 0.66 & 20 & 28.6 & 0.59 & 21 & 30.0 & \\
\hline \multirow[t]{2}{*}{ CYP3A4*IB } & Cambodia & 0.00 & 6 & 22.2 & 0.00 & 5 & 18.5 & Slight to substantial \\
\hline & Tanzania & 0.76 & 23 & 32.9 & 0.69 & 22 & 31.4 & \\
\hline \multirow[t]{2}{*}{ CYP $3 A 5 * 3$} & Cambodia & 0.39 & 21 & 77.8 & 0.42 & 17 & 63 & Fair to substantial \\
\hline & Tanzania & 0.73 & 61 & 87.1 & 0.65 & 58 & 82.9 & \\
\hline \multirow[t]{2}{*}{ NAT2 $* 5$} & Cambodia & 0.32 & 14 & 51.9 & 0.38 & 8 & 29.6 & Fair to moderate \\
\hline & Tanzania & 0.47 & 37 & 52.9 & 0.53 & 28 & 40.0 & \\
\hline \multirow[t]{2}{*}{$N A T 2 * 6$} & Cambodia & 0.70 & 26 & 96.3 & 0.73 & 25 & 92.6 & Substantial \\
\hline & Tanzania & 0.74 & 62 & 88.6 & 0.71 & 62 & 88.6 & \\
\hline \multirow[t]{2}{*}{ NAT2*7 } & Cambodia & 0.72 & 25 & 92.6 & 0.70 & 22 & 81.5 & Substantial \\
\hline & Tanzania & 0.75 & 55 & 78.6 & 0.67 & 49 & 70.0 & \\
\hline \multirow[t]{2}{*}{ NAT2* 14} & Cambodia & 1.00 & 27 & 100.0 & 1.00 & 27 & 100.0 & Substantial to almost \\
\hline & Tanzania & 0.76 & 62 & 88.6 & 0.74 & 61 & 87.1 & perfect \\
\hline
\end{tabular}

Data was acquired in 27 Cambodian and 70 Tanzanian malaria patients. $\kappa$ indicates the kappa index. $\mathrm{n}$ is the number and \% the percentage of samples with results for both techniques. 


\section{Data comparison}

SNP data gathered from sequencing and from microarray analysis were compared. Kappa statistics was used as an approach to the evaluation of agreement for the categorical data obtained by the two methods. The kappa index was calculated from contingency tables as follows $\kappa=((a$ $+\mathrm{b}) \times(\mathrm{a}+\mathrm{c})+(\mathrm{c}+\mathrm{d}) \times(\mathrm{b}+\mathrm{d})) /(\mathrm{a}+\mathrm{b}+\mathrm{c}+\mathrm{d})^{2}$

The kappa index was interpreted based on the criteria of Landis and Koch [37]. Hardy-Weinberg equilibrium was tested using the chi-square Hardy-Weinberg equilibrium test calculator for bi-allelic markers of the Online Encyclopedia for Genetic Epidemiology studies [38].

\section{Ethical approval}

All the applied protocols were approved by the ethics committee of the two cantons of Basel (Ethikkommission beider Basel, EKBB) and the responsible local authorities (i.e. in Tanzania from the Institutional Review Board of the Ifakara Health Institute and the National Institute for Medical Research Review Board and in Cambodia from the National Ethics Committee for Health Research). Blood samples were collected following written informed consent in the respective local language (Khmer or Swahili) from the participants or their guardians.

\section{Results}

Agreement between results obtained from sequencing and from the microarray on 18 SNPs within eight cyp isoen- zyme genes and nat 2 genes from 26 Cambodian and 70 Tanzanian malaria patients was tested. The results are summarized in Table 4. For some SNPs agreement ranged from substantial to almost perfect, whilst for other SNPs a large variability from slight to substantial agreement was found.

Where applicable, Chi-square Hardy-Weinberg equilibrium tests for the allele frequencies acquired by the microarray showed that most SNPs were significantly $(P<0.01)$ out of equilibrium (Table 5). Exceptions were CYP2D6*17 $(1023 \mathrm{C}>\mathrm{T})(P=0.50)$ for Tanzania after the $1^{\text {st }}$ wash; CYP2C8*3 $(P=0.92), C Y P 2 C 9 * 3(P=0.92)$, CYP2C9*5 $(P=0.92), C Y P 2 D 6 * 4(P=0.92)$ and CYP3A5*3 $(P=0.16)$ after the $1{ }^{\text {st }}$ wash and CYP3A5*3 $(P$ $=0.01)$ and NAT2 $(P=0.07)$ after the $2^{\text {nd }}$ wash for Cambodia.

In contrast, most allele frequencies acquired by sequencing were found to be in Hardy-Weinberg equilibrium (Table 6). However, in the Tanzanian study population CYP2B6*5 and CYP2D6*4 and in the Cambodian study population CYP $2 B 6^{*} 5, \quad C Y P 2 C 9 * 3, \quad C Y P 2 D 6 * 10$ (4180G>C), and CYP2D6*17 (2850C>T) were found not to have Hardy-Weinberg proportions.

\section{Discussion}

Comparison of data generated by microarray analysis with sequencing showed that the performance of the DNA

Table 5: Chi-square Hardy-Weinberg equilibrium tests for SNP data acquired by DNA microarray technology.

\begin{tabular}{|c|c|c|c|c|c|c|c|c|}
\hline \multirow[b]{3}{*}{ SNP } & \multicolumn{4}{|c|}{ Cambodia } & \multicolumn{4}{|c|}{ Tanzania } \\
\hline & \multicolumn{2}{|c|}{ Ist wash } & \multicolumn{2}{|c|}{$2^{\text {nd }}$ wash } & \multicolumn{2}{|c|}{ Ist wash } & \multicolumn{2}{|c|}{$2^{\text {nd }}$ wash } \\
\hline & $\chi^{2}$ & $P$ & $\chi^{2}$ & $P$ & $\chi^{2}$ & $P$ & $\chi^{2}$ & $P$ \\
\hline CYP2A6*2 & 23.00 & $<0.01$ & 7.29 & $<0.01$ & 23.57 & $<0.01$ & 34.02 & $<0.01$ \\
\hline CYP2B6*5 & N.A. & & N.A. & & 54.39 & $<0.01$ & 32.76 & $<0.01$ \\
\hline CYP2B6*6 & N.A. & & N.A. & & 16.90 & $<0.01$ & $|7.4|$ & $<0.01$ \\
\hline CYP2C8*3 & 0.01 & 0.92 & N.A. & & 8.22 & $<0.01$ & 39.35 & $<0.01$ \\
\hline CYP2C9*3 & 0.01 & 0.92 & N.A. & & 22.08 & $<0.01$ & 11.13 & $<0.01$ \\
\hline CYP2C9*5 & 0.01 & 0.92 & N.A. & & 14.69 & $<0.01$ & 14.30 & $<0.01$ \\
\hline CYP2CI9*3 & N.A. & & N.A. & & 18.22 & $<0.01$ & 9.98 & $<0.01$ \\
\hline CYP2D6*4 & 0.01 & 0.92 & N.A. & & 20.87 & $<0.01$ & 18.55 & $<0.01$ \\
\hline CYP2D6*I0 (100C>T) & 24.00 & $<0.01$ & 7.39 & $<0.01$ & 31.00 & $<0.01$ & 27.00 & $<0.01$ \\
\hline CYP2D6*I0 (4I80G>C) & 13.67 & $<0.01$ & N.A. & & 11.94 & $<0.01$ & 38.00 & $<0.01$ \\
\hline CYP2D6*I 7 (I023C>T) & 11.90 & $<0.01$ & 7.00 & $<0.01$ & 0.45 & 0.5 & 35.34 & $<0.01$ \\
\hline CYP2D6*I $7(2850 C>T)$ & 7.35 & $<0.01$ & 10.00 & $<0.01$ & 37.66 & $<0.01$ & 30.03 & $<0.01$ \\
\hline CYP3A4*IB & N.A. & & N.A. & & N.A. & & 24.00 & $<0.01$ \\
\hline CYP $3 A 5 * 3$ & 1.98 & 0.16 & 6.39 & 0.01 & 13.36 & $<0.01$ & 18.74 & $<0.01$ \\
\hline N.A.T2*5 & 8.41 & $<0.01$ & 3.32 & 0.07 & 13.83 & $<0.01$ & 13.70 & $<0.01$ \\
\hline N.A.T2*6 & N.A. & & N.A. & & 33.29 & $<0.01$ & 12.04 & $<0.01$ \\
\hline N.A.T2*7 & 9.97 & $<0.01$ & 8.63 & $<0.01$ & 30.21 & $<0.01$ & 24.82 & $<0.01$ \\
\hline N.A.T2* 14 & N.A. & & N.A. & & 32.08 & $<0.01$ & 19.30 & $<0.01$ \\
\hline
\end{tabular}

$\chi^{2}$ indicates the result from the Hardy-Weinberg equilibrium test, $P$ the one-tailed $P$-value, and N.A. that Chi-square could not be calculated because the allele frequency was either $0 \%$ or $100 \%$. 
microarray is limited. For some SNPs, i.e. CYP2A6*2, CYP2B6*5, CYP2C8*3, CYP2C9*3/*5, CYP2C19*3, CYP2D6*4 and NAT2*6/*7/*14, agreement ranged from substantial to almost perfect (kappa index between 0.61 and 1.00), whilst for other SNPs a large variability from slight to substantial agreement (kappa index between 0.39 and 1.00$)$ was found, e.g. CYP2D6*17 (2850C>T), $C Y P 3 A 4^{*} 1 B$ and $C Y P 3 A 5 * 3$. No clear trend in rise or decline of agreement between methods was visible from the $1^{\text {st }}$ to the $2^{\text {nd }}$ wash of the slide and thus it remains ambiguous whether repeated washing improves the performance of the microarray. However, agreement tends to be lower among the Cambodian samples. A possible explanation is the strong dependence of kappa on true prevalence of the SNPs [39] and the dissimilar distribution of the SNPs of interest in Cambodians and Tanzanians [40]. Furthermore, among most of these SNPs a considerable number of patient samples failed to yield a signal on the microarray (e.g. CYP2D6*17 $(2850 \mathrm{C}>\mathrm{T})$ and CYP CYP3A4*1B). The trend was clearly higher in samples from Tanzania, which might also be due to a lower quality of DNA arising from sub-optimal storage conditions after blood withdrawal. Sequencing data agreed with published reference sequences from public sources (Human Cytochrome P450 (CYP) Allele Nomenclature Committee [41]. The majority of samples genotyped by sequencing was found to be in Hardy-Weinberg equilibrium (exceptions were CYP2B6*5 in Cambodians and CYP2D ${ }^{*} 4$ in Tanzanians), proving that sampling was unbiased. The cases where population data generated by microarray was found not to be in Hardy-Weinberg proportion could be attributed to the large number of patient samples that failed to yield a signal on the microarray resulting in smaller simple size.

Because cyps evolved out of a single ancestor $[1,42]$, they show very close sequence similarities, which in turn makes it difficult to design gene specific primers, in particular extension primers that have to be designed at a defined position. It, therefore, became almost impossible to develop a single multiplex PCR and thus the microarray method described here is time consuming and laborious. This is in contrast to a similar microarray developed for the analysis of drug resistance associated SNPs in P. falciparum genes that permits the simultaneous analysis of many SNPs in hundreds of samples in a very short time period (approximately $15 \mathrm{~h}$ for four 96-well plates) with significantly reduced costs compared to other systems [5].

Furthermore, the costs of sequencing have decreased considerably during the last years and this trend may well continue. On the other hand, the costs of microarray reagents (especially Cy3- and Cy5-labeled ddNTPs that are used in three combinations) and glass slides for arraying have increased and are unlikely to decrease over time. So
Table 6: Chi-square Hardy-Weinberg equilibrium tests for SNP data acquired by sequencing.

\begin{tabular}{|c|c|c|c|c|}
\hline \multirow[b]{2}{*}{ SNP } & \multicolumn{2}{|c|}{ Cambodia } & \multicolumn{2}{|c|}{ Tanzania } \\
\hline & $\chi^{2}$ & $P$ & $\chi^{2}$ & $P$ \\
\hline CYP2A6*2 & N.A. & & N.A. & \\
\hline CYP2B6*5 & 10.86 & $<0.01$ & N.A. & \\
\hline CYP2B $6 * 6$ & 0.28 & 0.60 & 1.81 & 0.18 \\
\hline CYP2C $8 * 3$ & N.A. & & N.A. & \\
\hline CYP2C9*3 & 2.94 & 0.08 & N.A. & \\
\hline CYP2C9*5 & N.A. & & 0.14 & 0.71 \\
\hline $\mathrm{CYP} 2 \mathrm{CI} 19 * 3$ & N.A. & & N.A. & \\
\hline CYP2D $6 * 4$ & N.A. & & 15.75 & $<0.01$ \\
\hline CYP2D6*10 $(100 \mathrm{C}>\mathrm{T})$ & 1.39 & 0.24 & 1.34 & 0.25 \\
\hline CYP2D6*10 $(4 \mid 80 G>C)$ & 2.01 & 0.16 & 1.24 & 0.27 \\
\hline CYP2D6*17 (I023C>T) & N.A. & & 0.05 & 0.82 \\
\hline CYP2D6*I $7(2850 C>T)$ & 0.24 & 0.62 & 4.94 & 0.03 \\
\hline CYP $3 A 4 * I B$ & 0.10 & 0.75 & 0.04 & 0.84 \\
\hline СYР $3 A 5 * 3$ & 0.64 & 0.42 & 0.04 & 0.84 \\
\hline N.A.T2*5 & 0.10 & 0.75 & 0.01 & 0.92 \\
\hline N.A.T2*6 & 0.48 & 0.49 & 1.07 & 0.30 \\
\hline N.A.T2*7 & 0.01 & 0.92 & 0.14 & 0.71 \\
\hline N.A.T2*/4 & N.A. & & 5.02 & 0.03 \\
\hline
\end{tabular}

$\chi^{2}$ indicates the result from the Hardy-Weinberg equilibrium test, $P$ the one-tailed $P$-value, and N.A. that Chi-square could not be calculated because the allele frequency was either $0 \%$ or $100 \%$.

the costs for the microarray technology are not considerably lower anymore and, therefore, overall costs of both methods have become comparable.

While SNP analysis microarray has been successfully used to analyse point mutations in drug resistance associated genes in Plasmodium [5,43], it seems to fail with closely related genes, such as the human $c y p$ genes. For the latter, sequencing appears to be a more reliable method.

\section{Conclusion}

Although microarray allows the simultaneous determination of many SNPs, the lack of robustness for the described approach here prohibits its wide use in pharmacogenetics and sequencing occurs to be the more reliable technique. With the availability of large sequencing capacities worldwide, molecular-epidemiological studies using sequencing for a limited number of SNPs in CYP genes in a large population are feasible.

\section{Abbreviations}

Cy: Cyanine; CYP: Cytochrome P450; ddNTP: Dideoxynucleotide; DNA: Deoxyribonucleic acid; dNTP: Deoxynucleotide; EDTA: Ethylenediaminetetraacetic acid; NAT2: N-acetyletransferase-2; PCR: Polymerase chain reaction; PFCRT: Plasmodium falciparum chloroquine resistance transporter; RFLP: Restriction fragment length polymorphism; ROC: Receiver operating characteristic; SAP: Shrimp alkaline phosphatise; SDS: Sodium dodecyl 
sulphate; SNP: Single nucleotide polymorphism; SSC: Standard saline citrate; TE: Tris-EDTA

\section{Competing interests}

The authors declare that they have no competing interests. Support for this work was provided by grant No 320000112479 from the Swiss National Science Foundation.

\section{Authors' contributions}

EMH and SL were involved in microarray technology development and validation, data acquisition and analysis, and writing of the manuscript. WQ has developed the programme for the ROC analysis. FA was involved in the technology development. BG was involved in the overall pharmacogenetic project design and supervision. HPB was involved in the project design, technology development and in writing the manuscript

\section{Acknowledgements}

We would like to thank the patients who participated in the study and all the people involved in sample collection and we are grateful to the staff of the Center for Integrative Genomics in particular to Keith Hershman, Jérôme Thomas and Johann Weber for spotting the microarrays.

\section{References}

I. Ingelman-Sundberg M: The human genome project and novel aspects of cytochrome P450 research. Toxicol Appl Pharmacol 2005, 207(2 Suppl):52-56.

2. Ingelman-Sundberg M, Rodriguez-Antona C: Pharmacogenetics of drug-metabolizing enzymes: implications for a safer and more effective drug therapy. Philos Trans $R$ Soc Lond B Biol Sci 2005, 360( ( 460): I 563-1570.

3. Sobrino B, Brión M, Carracedo A: SNPs in forensic genetics: a review on SNP typing methodologies. Forensic Sci Int 2005, 154(2-3): 18I-94.

4. Sobrino $B$, Carracedo A: SNP typing in forensic genetics: a review. Methods Mol Biol 2005, 297: 107-26.

5. Crameri A, Marfurt J, Mugittu K, Maire N, Regös A, Coppee J, Sismeiro O, Burki R, Huber E, Laubscher D, Puijalon O, Genton B, Felger I, Beck HP: Rapid microarray-based method for monitoring of all currently known single-nucleotide polymorphisms associated with parasite resistance to antimalaria drugs. J Clin Microbiol 2007, 45(I I):3685-369I.

6. Miller J, Trepanier L: Inhibition by atovaquone of CYP2C9mediated sulphamethoxazole hydroxylamine formation. Eur J Clin Pharmacol 2002, 58(I):69-72.

7. Li X, Björkman A, Andersson T, Ridderström M, Masimirembwa C: Amodiaquine clearance and its metabolism to $\mathrm{N}$-desethylamodiaquine is mediated by CYP2C8: a new high affinity and turnover enzyme-specific probe substrate. J Pharmacol Exp Ther 2002, 300(2):399-407.

8. Khoo S, Back D, Winstanley P: The potential for interactions between antimalarial and antiretroviral drugs. AIDS 2005, 19(10):995-1005.

9. White N, van Vugt M, Ezzet F: Clinical pharmacokinetics and pharmacodynamics and pharmacodynamics of artemetherlumefantrine. Clin Pharmacokinet 1999, 37(2): I05-125.

10. Svensson U, Ashton M: Identification of the human cytochrome P450 enzymes involved in the in vitro metabolism of artemisinin. BrJ Clin Pharmacol 1999, 48(4):528-535.

II. Giao P, de Vries P: Pharmacokinetic interactions of antimalarial agents. Clin Pharmacokinet 200I, 40(5):343-373.

12. Li X, Björkman A, Andersson T, Gustafsson L, Masimirembwa C: Identification of human cytochrome $P(450)$ s that metabolise anti-parasitic drugs and predictions of in vivo drug hepatic clearance from in vitro data. Eur J Clin Pharmacol 2003, 59(56):429-442.
13. Grace J, Aguilar A, Trotman K, Peggins J, Brewer T: Metabolism of beta-arteether to dihydroqinghaosu by human liver microsomes and recombinant cytochrome P450. Drug Metab Dispos 1998, 26(4):3|3-3|7.

14. Projean D, Baune B, Farinotti R, Flinois J, Beaune P, Taburet A, Ducharme J: In vitro metabolism of chloroquine: identification of CYP2C8, CYP3A4, and CYP2D6 as the main isoforms catalyzing N-desethylchloroquine formation. Drug Metab Dispos 2003, 3 I (6):748-754.

15. Kim K, Park J, Lee J, Lim S: Cytochrome P450 2C8 and CYP3A4/ 5 are involved in chloroquine metabolism in human liver microsomes. Arch Pharm Res 2003, 26(8):631-637.

16. Halliday R, Jones B, Smith D, Kitteringham N, Park B: An investigation of the interaction between halofantrine, CYP2D6 and CYP3A4: studies with human liver microsomes and heterologous enzyme expression systems. Br J Clin Pharmacol 1995, 40(4):369-378.

17. Fontaine F, de Sousa G, Burcham P, Duchêne P, Rahmani R: Role of cytochrome P450 3A in the metabolism of mefloquine in human and animal hepatocytes. Life Sci 2000, 66(22):2193-2212.

18. Ridtitid W, Wongnawa M, Mahatthanatrakul W, Raungsri N, Sunbhanich M: Ketoconazole increases plasma concentrations of antimalarial mefloquine in healthy human volunteers. J Clin Pharm Ther 2005, 30(3):285-290.

19. Ridtitid W, Wongnawa M, Mahatthanatrakul W, Chaipol P, Sunbhanich M: Effect of rifampin on plasma concentrations of mefloquine in healthy volunteers. J Pharm Pharmacol 2000, 52(10): 1265-1269.

20. Kaneko A, Bergqvist $Y$, Taleo G, Kobayakawa T, Ishizaki T, Björkman $A$ : Proguanil disposition and toxicity in malaria patients from Vanuatu with high frequencies of CYP2CI9 mutations. Pharmacogenetics 1999, 9(3):317-326.

21. Skjelbo E, Mutabingwa T, Bygbjerg I, Nielsen K, Gram L, Brøosen K: Chloroguanide metabolism in relation to the efficacy in malaria prophylaxis and the S-mephenytoin oxidation in Tanzanians. Clin Pharmacol Ther 1996, 59(3):304-3II.

22. Mirghani R, Yasar U, Zheng T, Cook J, Gustafsson L, Tybring G, Ericsson $O$ : Enzyme kinetics for the formation of 3-hydroxyquinine and three new metabolites of quinine in vitro; 3 hydroxylation by CYP3A4 is indeed the major metabolic pathway. Drug Metab Dispos 2002, 30( ( 2):1368-137|.

23. Mirghani R, Hellgren U, Westerberg P, Ericsson O, Bertilsson L, Gustafsson L: The roles of cytochrome P450 $3 A 4$ and IA2 in the 3-hydroxylation of quinine in vivo. Clin Pharmacol Ther 1999, 66(5):454-460.

24. Zhang $\mathrm{H}$, Coville $P$, Walker R, Miners J, Birkett $D$, Wanwimolruk S: Evidence for involvement of human CYP3A in the 3-hydroxylation of quinine. BrJ Clin Pharmacol 1997, 43(3):245-252.

25. Barraviera B, Pereira P, Machado J, de Souza M, Lima C, Curi P, Mendes R, Meira D: Isoniazid acetylating phenotype in patients with paracoccidioidomycosis and its relationship with serum sulfadoxin levels, glucose-6-phosphate dehydrogenase and glutathione reductase activities. Rev Soc Bras Med Trop 24(2): III-II4.

26. Alfirevic A, Stalford A, Vilar F, Wilkins E, Park B, Pirmohamed M: Slow acetylator phenotype and genotype in HIV-positive patients with sulphamethoxazole hypersensitivity. $\mathrm{Br}$ J Clin Pharmacol 2003, 55(2): 158-165.

27. Daly A: Pharmacogenetics of the cytochromes P450. Curr Top Med Chem 2004, 4(16): I 733-1744.

28. Gil j: Amodiaquine pharmacogenetics. Pharmacogenomics 2008, 9(10):1385-1390.

29. Mehlotra R, Henry-Halldin C, Zimmerman P: Application of pharmacogenomics to malaria: a holistic approach for successful chemotherapy. Pharmacogenomics 2009, 1 0(3):435-449.

30. Tarning J, Bergqvist Y, Day N, Bergquist J, Arvidsson B, White N, Ashton $M$, Lindegådh $N$ : Characterization of human urinary metabolites of the antimalarial piperaquine. Drug Metab Dispos 2006, 34(I 2):201।-2019.

31. Klinker H, Langmann P, Richter E: Plasma pyrimethamine concentrations during long-term treatment for cerebral toxoplasmosis in patients with AIDS. Antimicrob Agents Chemother 1996, 40(7): 1623-1627.

32. Cavallito J, Nichol C, Brenckman WJ, Deangelis R, Stickney D, Simmons W, Sigel C: Lipid-soluble inhibitors of dihydrofolate 
reductase. I. Kinetics, tissue distribution, and extent of metabolism of pyrimethamine, metoprine, and etoprine in the rat, dog, and man. Drug Metab Dispos 6(3):329-337.

33. Lee J, Son J, Chung S, Lee E, Kim D: In vitro and in vivo metabolism of pyronaridine characterized by low-energy collisioninduced dissociation mass spectrometry with electrospray ionization. J Mass Spectrom 2004, 39(9): I036-1043.

34. Rolan P, Mercer A, Tate E, Benjamin I, Posner J: Disposition of atovaquone in humans. Antimicrob Agents Chemother 1997, $4|(6):| 3|9-| 32 \mid$.

35. Agwuh K, MacGowan A: Pharmacokinetics and pharmacodynamics of the tetracyclines including glycylcyclines. J Antimicrob Chemother 2006, 58(2):256-265.

36. Kestler H: ROC with confidence - a Perl program for receiver operator characteristic curves. Comput Methods Programs Biomed 200I, 64(2): 133-136.

37. Landis ], Koch G: The measurement of observer agreement for categorical data. Biometrics 1977, 33(1):159-174.

38. Online Encyclopedia for Genetic Epidemiology studies [http://www.oege.org/]

39. Thompson W, Walter S: A reappraisal of the kappa coefficient. J Clin Epidemiol 1988, 4 I ( I 0):949-958.

40. Vach W: The dependence of Cohen's kappa on the prevalence does not matter. J Clin Epidemiol 2005, 58(7):655-661.

41. Home Page of the Human Cytochrome P450 (CYP) Allele Nomenclature Committee [http://www.cypalleles.ki.se/]

42. Lewis D, Watson E, Lake B: Evolution of the cytochrome P450 superfamily: sequence alignments and pharmacogenetics. Mutat Res 1998, 410(3):245-270.

43. Ibrahim M, Steenkeste N, Khim N, Adam H, Konaté L, Coppée J, Ariey F, Duchemin J: Field-based evidence of fast and global increase of Plasmodium falciparum drug-resistance by DNAmicroarrays and PCR/RFLP in Niger. Malar J 2009, 8:32.

44. Consensus Human Arylamine N-Acetyltransferase Gene Nomenclature [http://louisville.edu/medschool/pharmacologyl NAT.html]

Publish with Biomed Central and every scientist can read your work free of charge

"BioMed Central will be the most significant development for disseminating the results of biomedical research in our lifetime. "

Sir Paul Nurse, Cancer Research UK

Your research papers will be:

- available free of charge to the entire biomedical community

- peer reviewed and published immediately upon acceptance

- cited in PubMed and archived on PubMed Central

- yours - you keep the copyright

Submit your manuscript here:

http://www.biomedcentral.com/info/publishing_adv.asp
BioMedcentral 